Amwaluna: Jurnal Ekonomi dan Keuangan Syariah Vol. 1 No.2 (Juli, 2017), Hal 231-245

Online ISSN : 2540-8402 | Print ISSN : 2540-8399

\title{
APLIKASI MAQASHID SYARIAH DALAM BIDANG PERBANKAN SYARIAH
}

\author{
Sandy Rizki Febriadi \\ Universitas Islam Bandung \\ Jl. Ranggagading No. 8 Bandung. Indonesia \\ prisha587@gmail.com
}

\begin{abstract}
Abstrak
Maqashid Syari'ah merupakan tujuan-tujuan umum yang ingin diraih oleh syariah dan diwujudkan dalam kehidupan. Maqashid Syariah merupakan konsep penting dalam kajian hukum Islam. Tujuan penelitian ini untuk mengetahui pengertian dan urgensi maqashid syari'ah dan untuk mengetahui sejarah dan klasifikasi maqashid syari'ah serta untuk mengetahui aplikasi maqashid syari'ah dalam bidang perbankan syari'ah. Metode penelitian yang digunakan yaitu yuridis normative, secara operasional penelitian yuridis normatif dilakukan dengan penelitian kepustakaan. Hasil penelitian ialah Maqashid Syari'ah tidak lahir secara tiba-tiba, tetapi melewati fase-fase, yaitu: fase pra kodifikasi, dan fase kodifikasi. Dalam sistem ekonomi yang hendak dibangun, sistem ekonomi dikatakan sukses berjalan apabila bisa mensejahterakan masyarakatnya. Maka sistem ekonomi harus bisa mengupayakan untuk mencapai tujuan utamanya, yaitu social welfare. Lahirnya bank syariah ditujukan untuk mewujudkan kesejahteraan umat secara luas. Dengan mengacu pada tujuan utama ini, istilah Maqashid Syari'ah menjadi sandaran utama dalam setiap pengembangan operasional dan produk yang ada di bank syariah.
\end{abstract}

\section{Keyword: Maqashid Syari'ah, Maslahat, Perbankan Syari'ah}

\begin{abstract}
Maqashid Shari'ah is the general goals that sharia wants to achieve and is realized in life. Maqashid Syariah is an important concept in the study of Islamic law. The purpose of this research is to find out the meaning and urgency of maqashid syari'ah and to find out the history and classification of maqashid syari'ah and to find out the application of maqashid syari'ah in the field of shari'ah banking. The research method used is juridical normative, operationally normative juridical research is carried out by library research. The results of the study were Maqashid Syari'ah not born suddenly, but passed through the phases, namely: the pre-codification phase, and the codification phase. In the economic system that is to be built, the economic system is said to be a successful running if it can prosper the people. Then the economic system must be able to strive to achieve its main goals, namely social welfare. The birth of Islamic banks is intended to realize the welfare of the people at large. By referring to this main objective, the term Maqashid Syari'ah is the main support in every operational development and product in Islamic banks.
\end{abstract}

\section{Keywords: Maqashid Sharia, Maslahah, Sharia Banking}

\section{PENDAHULUAN}

Maqashid Syari'ah merupakan tujuan-tujuan umum yang ingin diraih oleh syariah dan diwujudkan dalam kehidupan.
Maqashid Syariah salah satu konsep penting dalam kajian hukum Islam. Betapa pentingnya maqashid syari'ah tersebut, 
para ahli teori hukum menjadikan maqashid syari'ah sebagai ilmu yang harus dipahami oleh mujtahid yang melakukan ijtihad. Adapun inti dari teori maqashid syari'ah adalah untuk jalb al-masahalih wa daf'u al-mafasid atau mewujudkan kebaikan sekaligus menghindarkan keburukan, menarik manfaat dan menolak madharat. Maka istilah yang sepadan dengan inti dari maqashid syari'ah tersebut adalah maslahah (maslahat), karena penetapan hukum dalam Islam harus bermuara kepada maslahat.

Allah Swt sebagai syari' yang menetapkan syari'at tidak menciptakan hukum dan aturan begitu saja. Tetapi hukum dan aturan diciptakan dengan tujuan dan maksud tertentu. Ibnu Qayyim menyatakan bahwa tujuan syari'at adalah kemaslahatan hamba di dunia dan akhirat. Syari'at semuanya adil, semuanya berisi rahmat, dan semuanya mengandung hikmah. Setiap masalah yang menyimpang dari keadilan, rahmat, maslahat, dan hikmah pasti bukan ketentuan syari'at. (AlJauziyyah, 1991).

Di era modern ini, umat Islam dihadapkan pada perubahan-perubahan sosial yang telah menimbulkan sejumlah masalah serius berkaitan dengan hukum Islam. Di lain pihak, metode yang dikembangkan para mujtahid dalam menjawab permasalahan tersebut terlihat belum memuaskan. Dalam penelitian mengenai pembaruan hukum di dunia Islam, disimpulkan bahwa metode yang umumnya dikembangkan oleh mujtahid dalam menangani isu-isu hukum masih bertumpu pada pendekatan yang terpilahpilah dengan mengeksploitasi prinsip takhayyur dan talfiq. (Anderson, 1976: 42). Telah menjadi kebutuhan yang sangat mendesak bagi para mujtahid muslim saat ini untuk merumuskan suatu metodologi sistematis yang mempunyai akar Islam yang kokoh jika ingin menghasilkan hukum yang komprehensif dan berkembang secara konsisten. (Esposito, 1982: 101).

Penelitian ini bertujuan antara lain: pertama, untuk mengetahui pengertian dan urgensi maqashid syari'ah? Kedua, untuk mengetahui sejarah dan klasifikasi maqashid syari'ah? Ketiga, untuk mengetahui aplikasi maqashid syari'ah dalam bidang perbankan syari'ah. Berdasarkan uraian di atas, maka pengetahuan tentang maqashid syari'ah dalam kajian hukum Islam merupakan suatu keniscayaan. Penelitian singkat ini akan mencoba mengemukakan secara sederhana teori maqashid syari'ah tersebut. Dalam penelitian ini penulis menggunakan metode yuridis normatif yaitu penelitian hukum yang mempergunakan sumber data sekunder. Normatif, karena penelitian ini akan mengkaji dan menguji data-data sekunder 
Amwaluna: Jurnal Ekonomi dan Keuangan Syariah Vol. 1 No.2 (Juli, 2017), Hal 231-245

Online ISSN : 2540-8402 | Print ISSN : 2540-8399

yang bertitik tolak dari persoalan

penerapan maqashid syariah dalam bidang

perbankan syariah. Secara operasional

penelitian yuridis normatif dilakukan

dengan penelitian kepustakaan (Library

Reaseach).

Data penelitian pada umumnya terbagi kepada dua macam, antara lain: Pertama, data sekunder yang diperoleh melalui data-data kepustakaan. Data kepustakaan, dikenal juga studi literatur (Library Research) merupakan penelitian kepustakaan, yang dilakukan dengan mencari data dari buku, jurnal, peraturan perundang-undangan, dan tulisan-tulisan ilmiah lainnya. Pada penelitian ini akan diteliti maqashid syariah dengan referensi ayat-ayat Al-Quran, Hadits, dan kitabkitab para fuqaha. Kedua, data primer, yaitu data yang diperoleh langsung dari populasi dengan menggunakan metode wawancara atau menyebarkan kuisioner. Jenis dara ini dikenal dengan istilah Field Research (penelitian lapangan) yang pengumpulan datanya dilakukan dengan melakukan studi lapangan, baik dengan cara observasi, wawancara, angket, dan kuesioner. Teknik pengumpulan data pada penelitian ini menggunakan studi kepustakaan atau studi dokumen sebagai data sekunder yaitu menganalisis sumbersumber bacaan yang bersifat teoritis ilmiah yang relevan agar dapat dijadikan dasar analisis penelitian untuk memecahkan persoalan yang dikemukakan. Penelitian ini menggunakan teknik analisis dengan metode kualitatif melalui suatu cara penelitian yang menghasilkan data deskriptif analitis, karena tidak menggunakan rumus-rumus dan angkaangka dengan menggunakan metode berfikir deduktif.

\section{PEMBAHASAN}

\section{A. Pengertian dan Urgensi Maqashid Syari'ah}

Maqashid syari'ah menurut AlKhadimi (2001: 14). terdiri dari dua kata, maqashid dan syari'ah. Kata maqashid merupakan bentuk jama' dari maqshad yang berarti maksud dan tujuan. Ia merupakan mashdar mimi yang diambil dari kata kerja qashada, yaqshidu, qashdan. Secara bahasa, maqshad mempunyai beberapa pengertian: pertama, sandaran, pengarahan (penjelasan), dan istiqamah dalam menempuh jalan. Allah ta'ala berfirman: Dan hak bagi Allah (menerangkan) jalan yang lurus, dan di antara jalan-jalan ada yang bengkok. (QS. An-Nahl (16): 9). Kedua, pertengahan, tidak berlebihan dan juga tidak kekurangan. Firman Allah: Dan sederhanalah kamu dalam berjalan. (QS. Luqman (31): 19). 
Adapun syari'ah adalah kosa kata bahasa Arab yang secara harfiah berarti "jalan menuju sumber air" atau "sumber kehidupan". (Al-Fairūzābādiy, 1995: 659). Syariah adalah sumber air dan ia adalah tujuan bagi orang yang akan minum. (ArRazy, 1995: 141). Syariah juga ketetapan (aturan) Allah swt. kepada hamba-Nya berupa agama yang telah disyariahkan kepada mereka. Orang-orang Arab menerapkan istilah ini khususnya pada jalan setapak menuju sumber mata air yang tetap dan diberi tanda yang jelas terlihat mata. Jadi, syari'ah berarti jalan yang jelas kelihatan untuk diikuti. (Manzur). Al-Qur'an menggunakan kata syir'ah dan syariah dalam arti agama, atau dalam arti jalan yang jelas yang ditunjukkan Allah bagi manusia. Allah ta'ala berfirman: Untuk tiap-tiap umat diantara kamu, Kami berikan aturan dan jalan yang terang. (QS. Al-Maidah (5): 48). Juga kata syari'ah pada firman-Nya: Kemudian Kami jadikan kamu berada di atas suatu syariat (peraturan) dari urusan (agama itu), Maka ikutilah syariat itu dan janganlah kamu ikuti hawa nafsu orangorang yang tidak mengetahui. (QS. AlJatsiyah (45): 18).

Dari uraian di atas, kata syariah identik dengan sumber mata air karena air menjadi sumber kehidupan bagi manusia, hewan dan tumbuhan. Maka syari'ah (agama Islam) ini menjadi sumber kehidupan jiwa dan kemaslahatan yang dapat mengantarkan kepada keselamatan di dunia dan akhirat. Maka syari'ah menjadi sumber kehidupan, kebaikan dan kebahagiaan di dunia dan akhirat. Allah ta'ala berfirman: Hai orang-orang yang beriman, penuhilah seruan Allah dan seruan Rasul apabila Rasul menyeru kamu kepada suatu yang memberi kehidupan kepada kamu. (QS. Al-Anfal (8): 24). (AlKhadimi, 2001: 14). Maka kata syariah mempunyai pengertian hukum-hukum Allah yang ditetapkan untuk manusia agar dipedomani untuk mencapai kebahagiaan hidup di dunia maupun di akhirat.

Dengan demikian, kata maqashid syariah berarti tujuan dan rahasia yang telah ditetapkan syari' pada setiap hukumhukum-Nya. Menurut (Ar-Raisuni, 1992), maqashid syari'ah berarti tujuan yang ditetapkan syariat untuk kemaslahatan manusia. Maka maqashid syari'ah berarti kandungan nilai yang menjadi tujuan pensyariatan hukum. Maqashid syari'ah adalah tujuan-tujuan yang hendak dicapai dari suatu penetapan hukum. (Jaya, 1996: $5)$.

Izzuddin ibn Abd As-Salam, sebagaimana dikutip oleh (Umam, 2001), mengatakan bahwa segala taklif hukum selalu bertujuan untuk kemaslahatan hamba (manusia) dalam kehidupan dunia dan akhirat. Allah tidak membutuhkan ibadah seseorang, karena ketaatan dan 
Amwaluna: Jurnal Ekonomi dan Keuangan Syariah Vol. 1 No.2 (Juli, 2017), Hal 231-245

Online ISSN : 2540-8402 | Print ISSN : 2540-8399

maksiat hamba tidak memberikan

pengaruh apa-apa terhadap kemulian

Allah. Jadi, sasaran manfaat hukum tidak lain adalah kepentingan manusia.

Sementara itu Wahbah al-Zuhaili mendefinisikan maqashid syari'ah dengan makna-makna dan tujuan-tujuan yang dipelihara oleh syara' dalam seluruh hukumnya atau sebagian besar hukumnya, atau tujuan akhir dari syari'at dan rahasiarahasia yang diletakkan oleh syara' pada setiap hukumnya. (Az-Zuhaili, 1986: 1017).

Kajian teori maqashid syari'ah dalam hukum Islam adalah sangat penting. Urgensi itu didasarkan pada pertimbanganpertimbangan sebagai berikut. Pertama, hukum Islam adalah hukum yang bersumber dari wahyu Tuhan dan diperuntukkan bagi umat manusia. Oleh karena itu, ia akan selalu berhadapan dengan perubahan sosial. Dalam posisi seperti itu, apakah hukum Islam yang sumber utamanya (Al-Qur'an dan Sunnah) turun pada beberapa abad yang lampau dapat beradaptasi dengan perubahan sosial. Jawaban terhadap pertanyaan itu baru bisa diberikan setelah diadakan kajian terhadap berbagai elemen hukum Islam, dan salah satu elemen yang terpenting adalah teori maqashid syari'ah.

Kedua, dilihat dari aspek historis, sesungguhnya perhatian terhadap teori ini

telah dilakukan oleh Rasulullah Saw., para sahabat, tabi'in dan generasi mujtahid sesudahnya. Ketiga, pengetahuan tentang maqashid syari'ah merupakan kunci keberhasilan mujtahid dalam ijtihadnya, karena di atas landasan tujuan hukum itulah setiap persoalan dalam bermu'amalah antar sesama manusia dapat dikembalikan. (Khallaf, 1968) menyatakan bahwa nash-nash syari'ah itu tidak dapat dipahami secara benar kecuali oleh seseorang yang mengetahui maqashid syari'ah (tujuan hukum).

\section{B. Sejarah Dan Klasifikasi Maqashid Syari'ah}

Seperti halnya tabiat perkembangan ilmu-ilmu lain yang melewati beberapa fase mulai dari pembentukan hingga mencapai kematangannya, ilmu Maqashid Syariah pun tidak lepas dari proses ini. Maqashid Syari'ah tidak lahir secara tiba-tiba di dunia dan menjadi sebuah ilmu seperti saat ini, tetapi ia juga melewati fase-fase seperti di atas. Untuk lebih memudahkan dalam melihat fase perkembangan ini, maka akan dibagi menjadi dua fase; fase pra kodifikasi, dan fase kodifikasi.

Pertama, fase pra kodifikasi. Maqashid syariah sebenarnya sudah ada sejak nash Al-Qur'an diturunkan dan hadits disabdakan oleh Nabi. Karena 
maqashid syariah pada dasarnya tidak pernah meninggalkan nash, tapi ia selalu menyertainya. Seperti yang tercermin dalam ayat "wa ma arsalnaka illa rahmatan lil'alamin", bahwa Allah Swt. menurunkan syariat-Nya tidak lain adalah untuk kemaslahatan makhluk-Nya.

Oleh karena itu, setelah Nabi Saw. wafat dan wahyu terputus, sementara persoalan hidup terus berkembang, dan masalah-masalah baru yang tidak pernah terjadi pada masa Nabi menuntut penyelesaian hukum, maka para sahabat mencoba mencari sandarannya pada ayatayat Al-Quran maupun hadits, dan jika mereka tidak menemukan nash yang sesuai dengan masalah tadi pada Al-Quran maupun hadits, maka mereka akan berijtihad mencari hikmah-hikmah dan alasan dibalik ayat maupun hadits yang menerangkan tentang suatu hukum, jika mereka menemukannya maka mereka akan menggunakan alasan dan hikmah tersebut untuk menghukumi persolan baru tadi.

Pada umumnya para sahabat tidak mengalami kesulitan dalam menghukumi suatu persoalan baru yang muncul, karena mereka sehari-hari telah bergaul dengan Rasulullah Saw., mereka mengetahui peristiwa-peristiwa yang menjadi sebab diturunkannya sebuah ayat, mereka melihat bagaimana Nabi saw. menjalankan sesuatu atau meninggalkannya dalam situasi dan kondisi yang berlainan, mereka mengerti alasan kenapa Nabi Saw. lebih mengutamakan sesuatu dari pada yang lain dan seterusnya, yang hal ini semua pada akhirnya mengkristal dan melekat dalam diri mereka hingga kemudian membentuk rasa dan mempertajam intuisi serta cara berpikir mereka sesuai dengan maqashid syariah.

Diantara peristiwa-peristiwa baru yang muncul ketika masa sahabat dan tidak terjadi pada saat Nabi Saw. masih hidup antara lain, diriwayatkan bahwa Umar mendengar Hudzaifah telah menikah dengan seorang perempuan yahudi, kemudian Umar meminta Hudzaifah untuk menceraikannya. Karena Hudzaifah mengetahui bahwa pernikahan dengan ahli kitab diperbolehkan, maka ia pun bertanya kepada sahabat Umar, a haramun hiya? (apakah perempuan itu haram bagi saya?) Umar kemudian menjawab: tidak. Tapi saya khawatir ketika hal ini bisa menjadi fitnah bagi perempuan-perempuan muslimah, serta menyebabkan munculnya perzinahan. Atsar tersebut menjelaskan bahwa Umar melarang Hudzaifah menikahi perempuan Ahli Kitab. Karena dapat menimbulkan bahaya (dharar/keburukan) yaitu perbuatan zina dari kalangan muslimah atau sahabatsahabat lain akan mengikuti dan mencontoh dengan menikahi perempuan Ahli Kitab dan mengakibatkan banyaknya 
Amwaluna: Jurnal Ekonomi dan Keuangan Syariah Vol. 1 No.2 (Juli, 2017), Hal 231-245

Online ISSN : 2540-8402 | Print ISSN : 2540-8399

perempuan muslimah yang tidak menikah.

(Az-Zuhaily: 6655).

Contoh lainnya, kesepakatan para sahabat untuk melarang Abu Bakar bekerja dan berdagang untuk mencari nafkah bagi keluarganya ketika ia menjabat sebagai khalifah, dan akan mencukupi kebutuhan hidupnya serta keluarganya dari uang negara, demi kemaslahatan rakyat sehingga ia tidak sibuk memikirkan urusannya sendiri dan menelantarkan kepentingan rakyatnya. (Sa'ad, 1990).

Suatu saat Umar ra menjumpai orang yang menjual dagangannya di pasar dengan harga yang jauh lebih rendah dari harga umum. Maka ia kemudian mengancam orang tersebut dengan mengatakan; terserah kamu mau memilih, apakah barang daganganmu kamu naikkan seperti harga umum di pasar ini, atau kamu pergi membawa barang daganganmu dari pasar ini . Hal ini dilakukan Umar untuk menjaga stabilitas harga dan kemaslahatan umum. Dan masih banyak lagi contoh lain seperti pembukuan Al-Quran, pembuatan mata uang, pembagian ghanimah, shalat tarawih berjamaah, menggugurkan had sariqah pada musim krisis, dan sebagainya, yang mencerminkan kelekatan para sahabat dengan maqashid syariah.

Begitu pula ketika masa tabi'in, mereka bergerak dan melangkah pada jalan yang telah dilalui oleh guru-gurunya

yaitu para sahabat. Sehingga corak yang terlihat dalam penggunaan maqashid syariah untuk menyelesaikan masalahmasalah baru pada masa ini masih sama dengan masa sebelumnya. Misalnya tentang masalah tas'ir (penetapan harga untuk menjadi patokan umum) ketika harga kebutuhan-kebutuhan naik. Rasulullah saw. sendiri enggan menetapkan harga meskipun waktu itu harga-harga naik, dengan memberi isyarat bahwa tas'ir mengandung unsur tidak rela dan pemaksaan terhadap orang untuk menjual harganya. Namun Sa'id bin AlMusayyab dan Rabi'ah bin Abdurrahman mengeluarkan fatwa boleh tas'ir dengan alasan kemaslahatan umum, serta menjelaskan alasan kengganan Rasul untuk tas'ir adalah tidak adanya tuntutan yang medesak waktu itu, karena naiknya harga-harga dipicu oleh perubahan kondisi alam, yaitu kemarau panjang yang terjadi waktu itu. (Al-Jundi: 209). Sementara pada masa tabi'in kenaikan harga dipicu oleh merebaknya penimbunan barang, kerakusan para pedagang, serta melemahnya kecenderungan beragama, sehingga hal ini menuntut penetapan harga umum untuk menjaga keseimbangan dan menghindari praktek penimbunan.

Kedua, fase kodifikasi. Menurut Ar-Raisuni, barangkali orang yang paling awal menggunakan kata maqashid dalam 
judul karangannya adalah Al-Hakim AtTirmidzi (w. 320 H), yakni dalam bukunya As-Shalatu wa Maqasiduha. Tapi jika ditelusuri karangan-karangan yang sudah memuat tentang maqashid syari'ah, maka akan ditemukan jauh sebelum At-Tirmidzi. Karena Imam Malik (w. 179 H) dalam Muwaththa' sudah menuliskan riwayat yang menunjuk pada kasus penggunaan maqashid pada masa sahabat. Kemudian setelah itu diikuti oleh Imam Syafi'i (w. 204 H) dalam karyanya yang sangat populer Ar-Risalah, dimana ia telah menyinggung pembahasan mengenai ta'lil ahkam (pencarian alasan pada sebuah hukum), sebagian maqashid kulliyyah seperti hifdz an-nafs dan hifdz al-mal, yang merupakan cikal bakal bagi tema-tema ilmu maqashid.

Setelah Imam Syafi'i baru muncul Al-Hakim At-Tirmidzi, disusul Abu Bakar Muhammad Al-Qaffal al Kabir (w. 365 H) dalam kitabnya Mahasinu As- Syariah, yang mencoba membahas alasan-alasan dan hikmah hukum supaya lebih mudah dipahami dan diterima oleh manusia. Setelah itu datang Imam Haramain (w. 478 H) dalam kitabnya Al-Burhan yang menyinggung tentang dlaruriyyat, tahsiniyat dan hajiyat, yang juga menjadi tema pokok dalam Ilmu Maqashid. Kemudian datang Al-Ghazali (w. $505 \mathrm{H}$ ) yang membahas beberapa metode untuk mengetahui maqashid, dan menawarkan cara untuk menjaga maqashid syariah dari dua sisi al-wujud (yang mengokohkan eksistensinya) dan al-'adam (menjaga halhal yang bisa merusak maupun menggagalkannya). Kemudian Ar-Razi (w. $606 \mathrm{H}$ ), lalu Al-Amidi (w. $631 \mathrm{H}$ ), dan 'Izzuddin bin 'Abd As-Salam (w. 660 H), kemudian Al-Qarafi (w. 684 H), At-Thufi (w. $716 \mathrm{H}$ ), Ibnu Taimiyyah (w. 728 H), Ibnu Al-Qayyim Al-Jauziyyah (w. 751 H), baru setelah itu disusul oleh As-Syatibi (w. $790 \mathrm{H})$.

Dari sini kita bisa menyimpulkan bahwa dalam ilmu maqashid syariah AsSyatibi melanjutkan apa yang telah dibahas oleh ulama-ulama sebelumnya. Namun apa yang dilakukan oleh AsSyatibi bisa menarik perhatian banyak pihak karena ia mengumpulkan persoalanpersoalan yang tercecer dan dibahas sepotong-sepotong oleh orang-orang sebelumnya menjadi sebuah pembahasan tersendiri dalam kitabnya Al-Muwafaqat dimana ia mengkhususkan pembahasan mengenai maqashid ini dalam satu bagian kitabnya. Ia juga mengembangkan dan memperluas apa yang telah dibahas oleh ulama-ulama sebelumnya mengenai maqashid ini, juga menyusunnya secara urut dan sistematis seperti sebuah disiplin ilmu yang berdiri sendiri, sehingga lebih mudah untuk dipelajari. Hal inilah yang menjadi kontribusi signifikan As-Syatibi dalam ilmu maqashid syariah. 
Amwaluna: Jurnal Ekonomi dan Keuangan Syariah Vol. 1 No.2 (Juli, 2017), Hal 231-245

Online ISSN : 2540-8402 | Print ISSN : 2540-8399

Lebih jauh, hingga Ibnu 'Asyur (w.

$1393 \mathrm{H})$ pada akhirnya mempromosikan maqashid syariah ini sebagai sebuah disiplin ilmu yang berdiri sendiri. Pasca Ibn Asyur hingga saat ini, Maqashid alSyari'ah menapaki jalan menuju puncak kejayaan, dengan indikator utama dijadikanya Maqashid Syari'ah sebagai rujukan dan dalil pokok dalam menjawab sebagian besar persoalan kontemporer, terutama tentang hubungan Islam dengan modernitas, sosial, politik dan ekonomi global, serta persoalan membangun global ethics (etika global) dalam upaya merealisasikan perdamaian dunia. (Mawardi, 2010: 198-199).

$$
\text { Adapun berkenaan dengan }
$$

klasifikasi Maqashid Syari'ah, (AsSyatibi, 1997)membaginya kepada dua bagian:

1. Maqashid Syari', yaitu tujuantujuan yang diletakkan oleh Allah dalam mensyariatkan hukum. Menurut as-Syatibi, Maqasid Syari' terbagi empat bagian:
a. Tujuan Syari'
(Allah)
menciptakan Syariat.
b. Tujuan Syari' (Allah) menciptakan Syariat untuk difahami.
c. Tujuan Syari' (Allah) menjadikan Syariat untuk dipraktikkan.
d. Tujuan Syari' (Allah) meletakkan mukallaf di bawah hukum Syara'.

\section{Maqashid}

Al-Mukallaf, merupakan tujuan syariat bagi hamba (mukallaf) dalam melakukan sesuatu perbuatan. Maqashid al-mukallaf berperanan menentukan sah atau batal sesuatu amalan. kaidah berperan dalam maqashid al-mukallaf adalah: Maqashid al-mukallaf hendaklah selaras dengan maqashid syariah itu sendiri. Sehingga bila ada yang ingin mencapai sesuatu yang lain dari maksud awal pensyariatannya, sesuatu itu dianggap telah menyalahi syariat.

Selanjutnya pada pandangan AsSyatibi, tujuan Syari' (Allah) menciptakan syariat untuk merealisasikan kebaikan (maslahat) kepada hamba dan menolak keburukan (mafsadah) yang menimpa mereka. Dengan bahasa yang lebih mudah, aturan-aturan hukum yang Allah tentukan hanyalah untuk kemaslahatan manusia itu sendiri. As-Syathibi kemudian membagi maslahat ini kepada tiga bagian penting yaitu dharuriyyat (primer), hajiyyat (sekunder) dan tahsiniyat (tersier).

1. Ad-Dharuriyyat, yaitu sesuatu yang mesti ada demi terwujudnya kemaslahatan agama dan dunia. 
Apabila hal ini tidak ada, maka akan menimbulkan kerusakan bahkan hilangnya hidup dan kehidupan seperti makan, minum, shalat, shaum dan ibadah-ibadah lainnya. Termasuk maslahat atau maqashid dharuriyyat ini ada lima yaitu: agama (al-din), jiwa (annafs), keturunan (an-nasl), harta (al-mal) dan akal (al-aql). Cara untuk menjaga yang lima tadi dapat ditempuh dengan dua cara yaitu, pertama, dari segi adanya (min nahiyyati al-wujud) yaitu dengan cara menjaga dan memelihara halhal yang dapat melanggengkan keberadaannya. Kedua, dari segi tidak ada (min nahiyyati al-'adam) yaitu dengan cara mencegah halhal yang menyebabkan ketiadaannya.

2. Al-Hajiyat, yaitu sesuatu yang sebaiknya ada agar dalam melaksanakannya leluasa dan terhindar dari kesulitan. Jika sesuatu ini tidak ada, maka ia tidak akan menimbulkan kerusakan atau kematian hanya saja akan mengakibatkan masyaqqah dan kesempitan. Misalnya, dalam masalah ibadah adalah adanya rukhsah; shalat jama dan qashar bagi musafir. Dalam muamalah, syariat membolehkan jual beli yang merupakan pengecualian dari kaidah umum jual beli, seperti salam, ijarah, dan lainnya.

3. At-Tahsiniyat, yaitu sesuatu yang sebaiknya ada demi sesuainya dengan akhlak yang baik atau dengan adat. Jika sesuatu ini tidak ada, maka tidak akan menimbulkan kerusakan atau jika sesuatu itu hilang tidak akan menimbulkan masyaqqah dalam melaksanakannya, hanya saja dinilai tidak pantas dan tidak layak manurut ukuran tatakrama dan kesopanan. Di antara contohnya adalah thaharah, menutup aurat dengan pakaian yang bersih dan bagus, larangan israf, cara makan dan minum yang baik. Kondisi ini merupakan kondisi pelengkap hidup manusia, sehingga manusia merasakan kenyaman hidup.

\section{Aplikasi Maqashid Syari'ah Dalam Bidang Perbankan Syari'ah \\ Bank Syariah mulai dikembangkan} lagi sebagai solusi atas ketidakmampuan sistem ekonomi yang sedang berjalan selama ini dalam menghadapi permasalahan ekonomi yang semakin banyak dan komplek. Praktik dan prinsip kerja syariah tentunya dilandasi oleh nilainilai Islam yang terkandung di dalam AlQur'an, Hadits, dan sumber-sumber 
Amwaluna: Jurnal Ekonomi dan Keuangan Syariah Vol. 1 No.2 (Juli, 2017), Hal 231-245

Online ISSN : 2540-8402 | Print ISSN : 2540-8399

hukum Islam lainnya. Memang hal ini

akan terlihat sarat nilai, namun segala nilai

Islam ini sesungguhnya bersifat positif

sekaligus normatif dalam praktik pada

kehidupan nyata. Dalam perspektif sistem

perbankan ruang lingkup perbankan

syariah bersifat universal yaitu meliputi

kegiatan usaha komersial (commercial

banking) dan investasi (investment

banking). (Baraba, 1999)

Awal berdirinya bank syariah ditujukan untuk mencapai dan mewujudkan kesejahteraan umat secara luas dunia dan akhirat. Dengan mengacu pada tujuan utama ini, istilah Maqashid Syari'ah menjadi sandaran utama dalam setiap pengembangan operasional dan produk-produk yang ada di bank syariah. Oleh karena itu, semua pihak yang bekerja dalam bidang perbankan syariah harus bisa memahami betul apa dan bagaimana praktik dari prinsip maqashid syariah. Seperti yang telah dipaparkan di atas bahwa maqashid syariah (menuju syariah) dapat dicapai dengan terpenuhinya lima kebutuhan dasar manusia. Terdapat tiga tingkatan kebutuhan pada manusia, yaitu: dharruriyyat (primer), hajjiyat (sekunder), dan tahsiniyyat (tersier).

Manusia tidak diwajibkan untuk memenuhi ketiga tingkatan kebutuhan, tetapi diwajibkan untuk dapat memenuhi dengan baik kebutuhan dasar atau yang

disebut dengan kebutuhan dharruriyyat. Maksud memenuhi dengan baik di sini adalah bahwa dalam pemenuhannya harus diusahakan dengan cara-cara yang baik, benar, dan halal. Apabila manusia dapat terpenuhi kebutuhan dasarnya tersebut, inilah yang dimaksud dengan maqashid syariah. Kebutuhan dasar manusia tersebut terbagi dalam lima hal, yaitu: pertama, menjaga agama (ad-din). Kedua, menjaga jiwa (an-nafs). Ketiga, menjaga akal pikiran (al-aql). Keempat, menjaga harta (al-maal). Kelima, menjaga keturunan (annasl)

Oleh karena itu dapat dikatakan bahwa maqashid syariah dapat dicapai dengan terpenuhinya kelima kebutuhan dasar manusia tersebut. Begitu juga dalam sistem ekonomi yang hendak dibangun. Sistem ekonomi dikatakan sukses berjalan apabila bisa mensejahterakan masyarakatnya dan masyarakat dikatakan sejahtera apabila kebutuhan dasarnya tersebut terpenuhi. Jadi, sistem ekonomi beserta institusi-institusinya harus bisa mengupayakan hal ini untuk mencapai tujuan utamanya, yaitu social welfare. Berbagai jenis pembiayaan yang ditawarkan oleh perbankan syariah sebenarnya sangat mendukung kegiatan ekonomi dan industri. Tujuan dan fungsi perbankan syariah adalah kemakmuran ekonomi yang meluas, keadilan sosial 
ekonomi dan distribusi pendapatan serta kekayaan yang merata. (Iman Sugema: 2010).

Final goal atau tujuan utama tersebut dapat diusahakan salah satunya dalam sistem perbankan dimana saat ini sudah mulai banyak instansi berlombalomba mendirikan perbankan Islam untuk mencapai kemajuan ekonomi yang sesungguhnya. Dalam bank syariah, dalam hal ini dicontohkan Bank Muamalat Indonesia, berupaya untuk selalu memperbarui produknya dengan berlandaskan maqashid syariah. Produkproduk Bank Muamalat, antara lain: pertama, pendanaan, meliputi deposito dan tabungan mudharabah dan giro wadiah. Kedua, penyaluran dana, meliputi segi konsumen (dalam hal KPR dan dana haji) dan pembiayaan mudharabah dan musyarakah (investasi dan modal kerja). Ketiga, jasa/layanan, meliputi internet banking dan transfer.

Berikut peninjauan produk-produk dan operasional di bank syariah pada umumnya dengan nilai-nilai maqashid syariah:

1. Menjaga agama. Hal ini diwujudkan dengan Bank Muamalat menggunakan AlQur'an, hadits, dan hukum Islam lainnya sebagai pedoman dalam menjalankan segala sistem operasional dan produknya.
Dengan adanya Dewan Pengawas Syariah dan Dewan Syariah Nasional, membuat keabsahan bank tersebut dalam nilai-nilai dan aturan Islam semakin terjamin dan Insya Allah dapat dipercaya oleh kalangan muslim dan non-muslim.

2. Menjaga jiwa. Hal ini terwujud dari akad-akad yang diterapkan dalam setiap transaksi di bank syariah. Secara psikologis dan sosiologis penggunaan akad-akad antar pihak menuntun manusia untuk saling menghargai dan menjaga amanah yang diberikan. Di sinilah nilai jiwanya. Selain itu, hal ini juga terwujud dari pihak stakeholder dan stockholder bank syariah dimana dalam menghadapi nasabah dituntut untuk berperilaku, berpakaian, dan berkomunikasi secara sopan dan Islami.

3. Menjaga akal pikiran baik pihak nasabah dan pihak bank. Hal ini terwujud dari adanya tuntutan bahwa pihak bank harus selalu mengungkapkan secara detail mengenai sistem produknya dan dilarang untuk menutup-nutupi barang sedikit pun. Di sini terlihat bahwa nasabah diajak untuk berpikir bersama ketika melakukan transaksi di bank tersebut tanpa ada yang dizalimi oleh pihak bank. 
Amwaluna: Jurnal Ekonomi dan Keuangan Syariah Vol. 1 No.2 (Juli, 2017), Hal 231-245

Online ISSN : 2540-8402 | Print ISSN : 2540-8399

Bank syariah ikut mencerdaskan nasabah dengan adanya edukasi di setiap produk bank kepada nasabah

4. Menjaga harta. Hal ini terwujud jelas dalam setiap produk-produk yang dikeluarkan oleh bank dimana bank berupaya untuk menjaga dan mengalokasikan dana nasabah dengan baik dan halal serta diperbolehkan untuk mengambil profit yang wajar. Selain itu, terlihat juga dari adanya penerapan sistem zakat yang bertujuan untuk membersihkan harta nasabah secara transparan dan bersamasama.

5. Menjaga keturunan. Hal ini terwujud dengan terjaganya empat hal di atas, maka dana nasabah yang Insya Allah dijamin halal akan berdampak baik bagi keluarga dan keturunan yang dinafkahi dari dana tabungan maupun usahanya tersebut.

\section{SIMPULAN}

Pada bagian penutup ini akan disampaikan beberapa kesimpulan dari pembahasan Maqashid Syariah sebagaimana berikut: Pertama, Maqashid syari'ah berarti tujuan yang ditetapkan syariat untuk kemaslahatan manusia. Secara singkat, maqashid syari'ah ialah tujuan-tujuan yang hendak dicapai dari suatu penetapan hukum. Demikian pentingnya maqashid syari'ah, karena nash-nash syari'ah itu tidak dapat dipahami secara benar kecuali oleh seseorang yang mengetahui tujuan hukum.

Maqashid Syari'ah tidak lahir secara tiba-tiba sebagai sebuah ilmu seperti saat ini, tetapi ia melewati fase-fase perkembangan yang dibagi menjadi dua fase: fase pra kodifikasi, dan fase kodifikasi. Pada dasarnya, aturan-aturan hukum yang Allah tetapkan bertujuan hanyalah untuk kemaslahatan manusia itu sendiri. As-Syathibi membagi kemaslahatan ini kepada tiga bagian penting yaitu dharuriyyat (primer), hajiyyat (sekunder) dan tahsiniyat (tersier).

Lahirnya bank syariah ditujukan untuk mencapai dan mewujudkan kesejahteraan umat secara luas dunia dan akhirat. Dengan mengacu pada tujuan utama ini, istilah Maqashid Syari'ah menjadi sandaran utama dalam setiap pengembangan operasional dan produkproduk yang ada di bank syariah. Oleh karena itu, semua pihak yang bekerja dalam bidang perbankan syariah harus bisa memahami betul apa dan bagaimana praktik dari prinsip maqashid syariah. 


\section{Daftar Pustaka}

A. Evita Isretno Israhadi, Investasi Bagi Hasil Dalam Pembiayaan Akad Mudharabah Perbankan Syariah. Jurnal Lex Publika, Vol.1, No. 1, Januari 2014.

Abd Al-Halim Al-Jundi. Al-Imam AsSyafi'i: Nashir As-Sunnah wa Wadi' Al-Ushul. Cairo: Daar AlMa’arif.

Ahmad Imam Mawardi. (2010). Fiqh Minoritas fiqh al-Aqlliyat dan Evolusi Maqashid As-Syari'ah dari Konsep ke Pendekatan. Yogyakarta: Lkis.

Al-Jauziyyah, I. Q. (1991). I'lam Al-

Muwaqqi'in 'an Rabb Al-'Alamin. Beirut:

Daar Al-Kutub Al-'Ilmiyah.

Ar-Raisuni, A. (1992). Nadzariyah Almaqashid 'Inda As-Syatibi. Daar AlAlamiyah Li Al0Kitab Al-Islami.

Asafri Jaya. (1996). Konsep Maqashid AsSyari'ah Menurut As-Syathibi. Jakarta:

Raja Grafindo Persada

As-Syatibi. (1997). Al-Muwafaqat. Mesir:

Daar Ibn 'Affan.

Baraba, A. (1999). Prinsip Dasar

Operasional Perbankan Syariah. Buletin Ekonomi Moneter dan Perbankan, Vol 2 NO.3.
Halima Boukerraucha, Book Review: Islamic Legal Maxims and Their Application in Islamic Finance, ISRA International Arabic Journal of Islamic Finance, Vol. 5, June 2014.

J.N.D. Anderson. (1976). Law Reform in the Muslim World. London: University of London Press.

John L. Esposito. (1982). Women in Muslim Family Law. Syracuse: Syracuse University Press.

Khallaf, A. A.-W. (1968). Ilmu Ushul Al-

Fiqh. Cairo: Maktabah Ad-Da'wah AlIslamiyah.

Manzur, I. Lisan Al-Arab. Mesir: Dar AlShadr.

Muhammad bin Abi Bakr bin Abd alQadir Ar-Raziy. (1995). Mukhtar As-Shihah. Beirut: Maktabah Lubnan Nasyrirun.

Muhammad Ibn Ya'qūb al-Fairūzābādiy. (1995). Al-Qāmūs al-Muhìth. Beirut: Dār al-Fikr.

Nuur Ad-Diin bin Mukhtar Al-Khadimi. (2001). Ilmu Al-Maqashid AsSyariah. Beirut: Maktabah AlUbaikan.

Sa'ad, I. (1990). At-Thabaqat Al-Kubra.

Bairut: Daar Al-Kutub Al-'Ilmiyah.

Umam, K. (2001). Ushul Fiqh. Bandung:

Pustaka Setia. 
Amwaluna: Jurnal Ekonomi dan Keuangan Syariah Vol. 1 No.2 (Juli, 2017), Hal 231-245

Online ISSN : 2540-8402 | Print ISSN : 2540-8399

Wahbah Az-Zuhaili. (1986). Ushul AlInternational Monetary Fund,

Fiqh Al-Islami. Beirut: Dar AlVol. 34, No. 2, June 1997.

Fikr.

Wahbah Az-Zuhaily. Al-Fiqh Al-Islami wa Adillatuhu. Damaskus: Daar AlFikr.

Zamir Iqbal, Islamic Financial Systems:

Finance and Development, http://www.agustiantocentre.com/?p=1436 http://www.muamalatbank.com/home/prod uk/deposito_mudharabah https://alimprospect.wordpress.com/2013/ 02/27/maqashid-sejarah-perkembanganmaqashid-syariah/ 